\title{
Two-Site "Simultaneous" Immunoassay with Monoclonal Antibodies for the Determination of Surfactant Apoproteins in Human Amniotic Fluid
}

\author{
YOSHIO KUROKI, HIROKI TAKAHASHI, YOSHITAKA FUKADA, MAKOTO MIKAWA, \\ AKIRA INAGAWA, SEIICHIRO FUJIMOTO, AND TOYOAKI AKINO \\ Department of Biochemistry [Y.K., H.T., Y.F., T.A.], Sapporo Medical College, South-1, West-17, Chuo-Ku, \\ Sapporo, and Division of Delivery [M.M., S.F.], Hokkaido University Hospital, North-15, West-7, \\ Kita-Ku, Sapporo, Japan
}

\begin{abstract}
Monoclonal antibodies against human surfactant apoproteins were prepared, which recognized 37 , 34 , and 62 kilodalton proteins in human lung lavage fluid and amniotic fluid. Two-site "simultaneous" immunoassay for the surfactant apoproteins was developed using the monoclonal antibodies. The assay was capable of measuring 10-640 $\mathrm{ng}$ of the apoproteins per $\mathrm{ml}$ of human amniotic fluid. The immunoassay was used to quantitate the apoproteins in 59 amniotic fluid samples from 23 to 41 wk gestation. The concentration of the surfactant apoproteins at less than 30 wk gestation was very low (mean $0.84 \mu \mathrm{g} /$ $\mathrm{ml}$ ). It then increased 6.5 -fold from 34 to 36 wk gestation and 15.5-fold at more than 37 wk gestation. The simultaneous immunoassay with the monoclonal antibodies presented herein seems to be ideal for clinical use because of its high specificity, sensitivity, rapidity, simplicity, and a continuous unlimited supply of the antibodies. The results in this study show that the clinical use of the two-site simultaneous immunoassay with monoclonal antibodies to pulmonary surfactant apoproteins can predict fetal lung maturity more precisely. (Pediatr Res 19: 1017-1020, 1985)
\end{abstract}

\section{Abbreviations}

KDa, kilodalton

PBS, phosphate-buffered saline, pH 7.4

TX/SM/PBS, $2 \%$ skim milk in PBS containing 1\% Triton $\mathrm{X}-\mathbf{1 0 0}$

Pulmonary surfactant stabilizes the alveoli by lowering the surface tension on expiration, thus preventing alveolar collapse (1). A deficiency in the pulmonary surfactant is believed to cause the respiratory distress syndrome in newborn humans. Fetal lung maturity has been assessed by the phospholipid analysis of surfactant in the amniotic fluid. On the other hand, King et al. (2) reported that the change in the concentration of pulmonary surfactant apoproteins in amniotic fluid was approximately parallel with that of the phospholipid concentration. They used a semiquantitative latex agglutination assay for the determination of the apoproteins. Recently, Katyal and coworkers $(3,4)$ re-

Received March 28, 1985; accepted May 21, 1985

Requests for reprints should be addressed to Dr. Toyoaki Akino, Department of Biochemistry, Sapporo Medical College, South-1, West-17, Chuo-Ku, Sapporo, 060 Japan.

Supported by a Grant-Aid for Scientific Research from the Ministry of Education, Science and Culture, Japan and a grant from Kieikai Foundation. ported an enzyme-linked immunoassay to quantitate surfactant apoproteins using polyclonal antibodies.

Since hybridoma technology was introduced by Köhler and Milstein (5), monoclonal antibodies have been used as replacements for polyclonal sera in some of the classical immunoassays. Several investigators $(6,7)$ reported the advantages of monoclonal antibodies in the immunoassay compared to that of polyclonal antibodies.

We have prepared monoclonal antibodies against human surfactant apoproteins (8). In the present study we describe a twosite "simultaneous" immunoassay with the monoclonal antibodies and its application for clinical use to quantitate surfactant apoproteins in human amniotic fluid.

\section{MATERIALS AND METHODS}

Isolation of surfactant apoproteins. Human pulmonary surfactant was isolated from the lung lavage fluids of patients with alveolar proteinosis using the modified method described by Frosolono et al. (9). The surface active fraction obtained by discontinuous sucrose density gradient centrifugation of the lavage fluid was treated by $5 \mathrm{mM}$ Tris buffer, $\mathrm{pH} 7.8$ containing $1 \%(\mathrm{v} / \mathrm{v})$ Triton X-100, $3 \mathrm{mM}$ EDTA, $1 \mathrm{mM}$ phenylmethylsulfonylfluoride, $0.5 \mathrm{mM}$ dithiothreitol (Triton buffer), and was delipidated with butanol-ethanol extraction. The delipidated material was treated with the Triton buffer and then centrifuged. After the centrifugation the supernatants were applied to a Blue Sepharose column (Pharmacia Fine Chemicals, Uppsala, Sweden). The fractions not bound to the Blue Sepharose column were then applied to a DEAE-Toyopearl column (Toyo Jyozo Co., Tokyo, Japan). After the initial washing with Triton buffer, the column was developed with a linearly increasing concentration of $0-0.5 \mathrm{M} \mathrm{NaCl}$ in the same buffer. Proteins contained in the main fractions were separated with sodium dodecyl sulfatepolyacrylamide gel electrophoresis by the method of Laemmli (10). The protein content of each fraction was estimated by the method of Lowry et al. (11). The main peaks eluted with $\mathrm{NaCl}$ concentration between 0.30 and $0.35 \mathrm{M}$ on the DEAE-Toyopearl column chromatography, which contained 62 and $36 \mathrm{KDa}$ protein, were collected and used as pulmonary surfactant apoproteins in the present study.

Preparation of monoclonal antibodies against human pulmonary surfactant apoproteins. The isolated pulmonary surfactant apoproteins were emulsified in Freund's complete adjuvant and injected into the peritoneal cavities of $\mathrm{BALB} / \mathrm{c}$ mice. The immune cells isolated from the mice were fused with P3-X63-Ag8U1 using $50 \%$ polyethyleneglycol 4000 (12). Antibody activity of the culture medium was examined by the enzyme linked immunosorbent assay described elsewhere (8). The monoclonal 
antibodies finally obtained, i.e. PC 6 and PE 10, were amplified by growing hybrid cells as ascites in pristane-treated BALB/c mice. Ascites obtained from tumor-bearing mice was applied to a Protein A-Sepharose CL 4B column (Pharmacia Fine Chemicals) after being precipitated with $50 \%$ saturated ammonium sulfate. Pure $\operatorname{IgG}$ was eluted with $0.2 \mathrm{M}$ glycinehydrochloride buffer, pH 3.0 (13).

Biotin labeling of monoclonal antibody. N-hydroxysuccinimidobiotin (NHS-biotin, Pierce Chemicals, Rockford, IL) was used for introducing biotin moieties into monoclonal antibody. Pure immunoglobulin $(1.0 \mathrm{mg} / \mathrm{ml})$ was dialyzed against $0.1 \mathrm{M}$ sodium bicarbonate. After dialysis 10 volumes of pure immunoglobulin were mixed with 1 volume of NHS-biotin solution $(1.0 \mathrm{mg} / \mathrm{ml}$ in dimethylsulfoxide). The reaction mixture was incubated at room temperature for $4 \mathrm{~h}$ and then dialyzed for $24 \mathrm{~h}$ at $4^{\circ} \mathrm{C}$ against several changes of $50 \mathrm{mM}$ PBS.

Two-site simultaneous immunoassay. The two-site simultaneous immunoassay was carried out using two monoclonal antibodies, i.e.. PC 6 and PE10. Wells in the nontreated microtiter plates (Dynatech Laboratories Inc., Alexandria, VA) containing $200 \mu \mathrm{l}$ of monoclonal antibody $\mathrm{PC} 6(10 \mu \mathrm{g} / \mathrm{ml}$ in $0.1 \mathrm{M}$ sodium bicarbonate) were incubated overnight at $20^{\circ} \mathrm{C}$. The wells were then washed with $2 \%$ skim milk (Snow Brand Milk Product Co. Ltd., Sapporo, Japan) in PBS containing 1\% Triton X-100 (TX/ $\mathrm{SM} / \mathrm{PBS}$ ) for $30 \mathrm{~min}$ at room temperature. The plates thus prepared were stored at $-20^{\circ} \mathrm{C}$ until used. Each plate was returned to room temperature immediately before the immunoassay. After washing the plate with TX/SM/PBS, aliquots $(100 \mu \mathrm{l})$ containing $10 \mathrm{ng}$ to $100 \mu \mathrm{g}$ of purified apoproteins per $\mathrm{ml}$ (in TX/SM/PBS) or various dilutions (2 to 256 times) of amniotic fluid samples (in TX/SM/PBS), and $100 \mu \mathrm{l}$ of biotinylated monoclonal antibody PE $10(2 \mu \mathrm{g} / \mathrm{ml}$ in TX/SM/PBS) were simultaneously added to the antibody PC 6 coated wells. The wells were incubated at $37^{\circ} \mathrm{C}$ for $90 \mathrm{~min}$ and washed with TX/SM/PBS. Two hundred $\mu$ l of horseradish peroxidase avidin $\mathrm{D}$ (Vector Laboratories, Inc., Burlingame, CA, diluted to 1200 times in TX/SM/PBS) were added to each well. The wells were then incubated at room temperature for $20 \mathrm{~min}$. After extensive washings with PBS containing $1 \%$ Triton X-100, $200 \mu$ l of the substrate solution $(0.1 \% o$-phenylenediamine, $0.015 \%$ hydrogen peroxide, $0.1 \mathrm{M}$ citrate buffer $\mathrm{pH} 4.6$ ) were added. The reaction was carried out for $30 \mathrm{~min}$ at room temperature and was stopped by the addition of $100 \mu \mathrm{l}$ of $2 \mathrm{M}$ sulfuric acid. The absorbance of each well was measured using an automatic microplate reader at two wave length absorbances; $\mathrm{OD}_{500 \mathrm{~nm}}-\mathrm{OD}_{610 \mathrm{~nm}}$.

Immunoassay of surfactant apoproteins in human amniotic fluid. The samples of amniotic fluid from 23 to 41 wk gestation were obtained by transabdominal amniocentesis or vaginal collection at the Hokkaido University Hospital and Asahikawa Medical College Hospital in Japan. The amniotic fluids were centrifuged at $300 \times g$ for $10 \mathrm{~min}$ to remove cellular debris. The supernatants after centrifugation were frozen until the analysis of surfactant apoproteins could be made. The samples from complicated pregnancies such as diabetes, $\mathrm{Rh}$ incompatibility or rupture of membranes more than $24 \mathrm{~h}$ before delivery, with blood or meconium contamination, with polyhydroamnions, or with the use of prenatal glucocorticoids for the prevention of respiratory distress syndrome were all eliminated in the present study. Fifty-nine samples remained after the elimination. The samples were analyzed by the two-site simultaneous immunoassay method mentioned above.

\section{RESULTS}

Specificity of monoclonal antibodies. The specificity of two monoclonal antibodies used in the immunoassay has been described in detail elsewhere (8). It was shown by immunoblotting (14) that monoclonal antibodies PC 6 and PE 10 recognize the same proteins, i.e. $34 \mathrm{KDa}, 37 \mathrm{KDa}$, and $62 \mathrm{KDa}$ proteins in human lung lavage fluid and amniotic fluid. The monoclonal antibodies were specific only for the human lung. They did not react with serum proteins, indicating that the surfactant apoproteins isolated are not derived from serum.

Immunoassay of surfactant apoproteins. The pulmonary surfactant apoproteins isolated from lung lavage fluids of patients with alveolar proteinosis were used as the standard for the immunoassay. Figure 1 shows a calibration curve of the apoproteins by the two-site simultaneous immunoassay. The assay was capable of measuring 10-640 $\mathrm{ng}$ of the apoproteins per ml with a coefficient of variation of less than $6 \%$. The calibration curve obtained with different concentrations of the apoprotein standards were almost superimposable with those of amniotic fluid from a term pregnancy and bronchoalveolar lavage fluid from an adult man (Fig. 2). Addition of human serum (2\%) to the standard apoprotein preparations and to the amniotic fluid samples did not change the assayed concentration of the apoproteins, indicating that the immunoassay is free of serum interference. When the apoproteins were assayed at high concentrations of up to $100 \mu \mathrm{g} / \mathrm{ml}$ by the simultaneous immunoassay, the high-dose hooking effect was observed at the apoprotein concentration of more than $50 \mu \mathrm{g} / \mathrm{ml}$ (Fig. 3).

Correlation of apoprotein concentration with gestational ages. The apoprotein concentrations of 59 samples of human amniotic fluid drawn at the various gestational ages were determined. The results are shown in Figure 4 and Table 1. The apoprotein concentration was very low $(0.84 \mu \mathrm{g} / \mathrm{ml})$ in samples from pregnancies of less than $30 \mathrm{wk}$ gestation. The concentration increased dramatically during the latter stages of gestation. The apoprotein concentrations in amniotic fluid from four patients who developed respiratory distress syndrome were $0.08,0.16,0.10$, and $0.56 \mu \mathrm{g} / \mathrm{ml}$, respectively.

\section{DISCUSSION}

The present study describes the two-site simultaneous immunoassay for the determination of surfactant apoproteins using

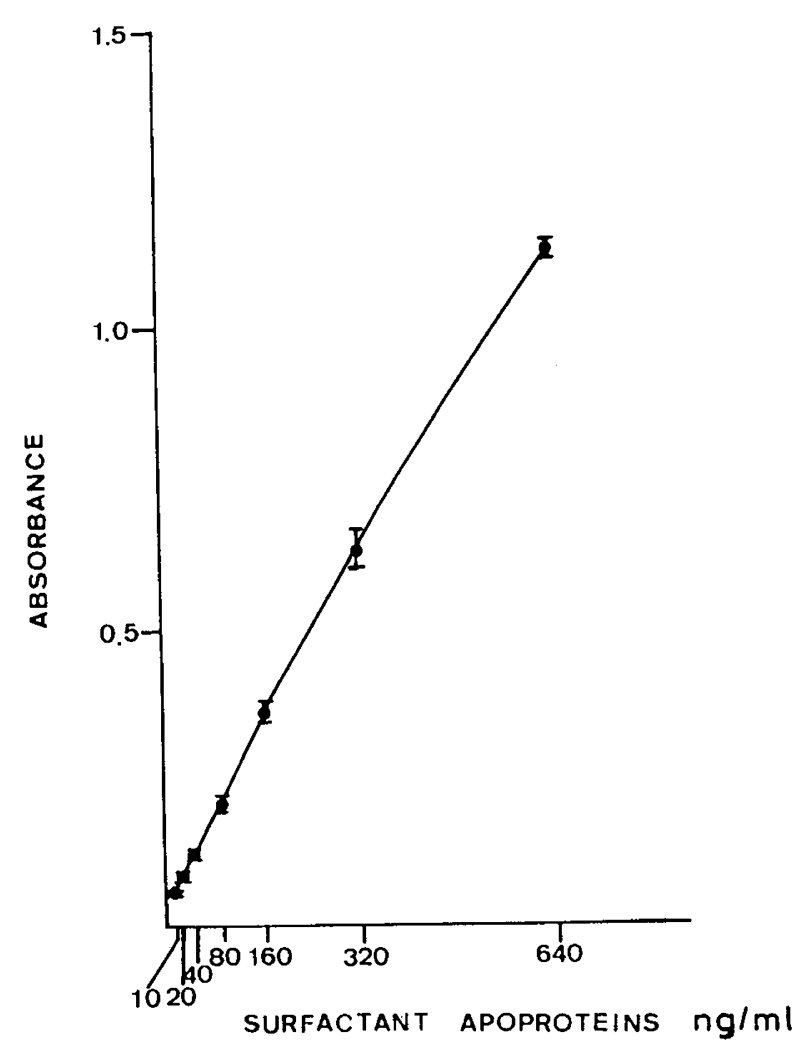

Fig. 1. Two-site simultaneous immunoassay with monoclonal antibodies for the determination of surfactant apoproteins. The absorbance was measured at $\mathrm{OD}_{500 \mathrm{~nm}}-\mathrm{OD}_{610 \mathrm{~nm}}$. Each point represents the mean \pm $\mathrm{SD}$ of five determinations. 


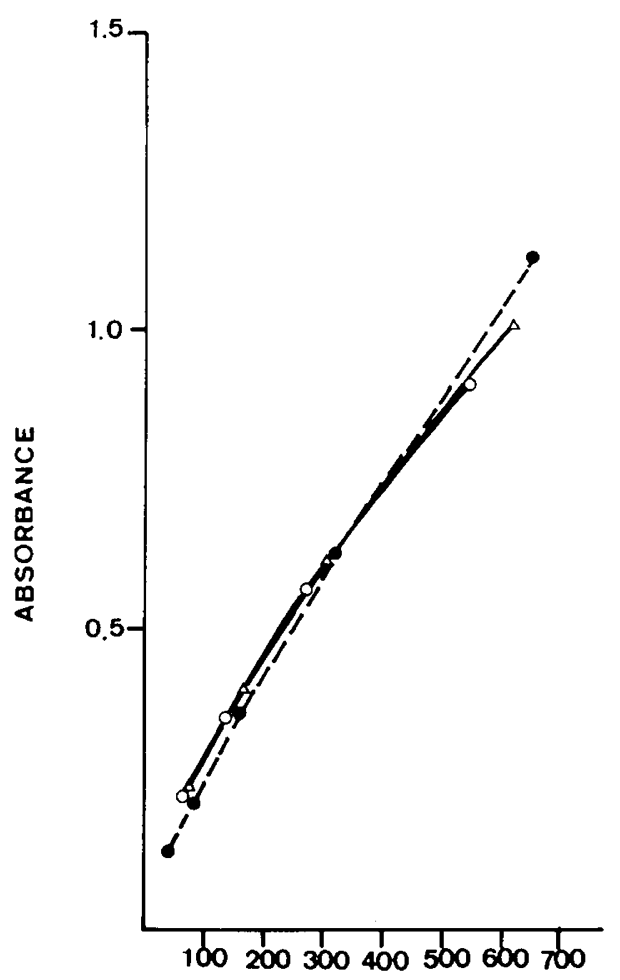

SURFACTANT APOPROTEINS $\mathrm{ng} / \mathrm{ml}$

Fig. 2. Comparison of calibration curves obtained for dilutions of amniotic fluid from a woman at $40 \mathrm{wk}$ gestation $\left(\mathrm{O}_{-} \mathrm{O}\right.$ ), or bronchoalveolar lavage fluid from adult $\operatorname{man}(\triangle \longrightarrow \triangle)$, and purified surfactant apoproteins (-- Values are the mean of duplicate assays.

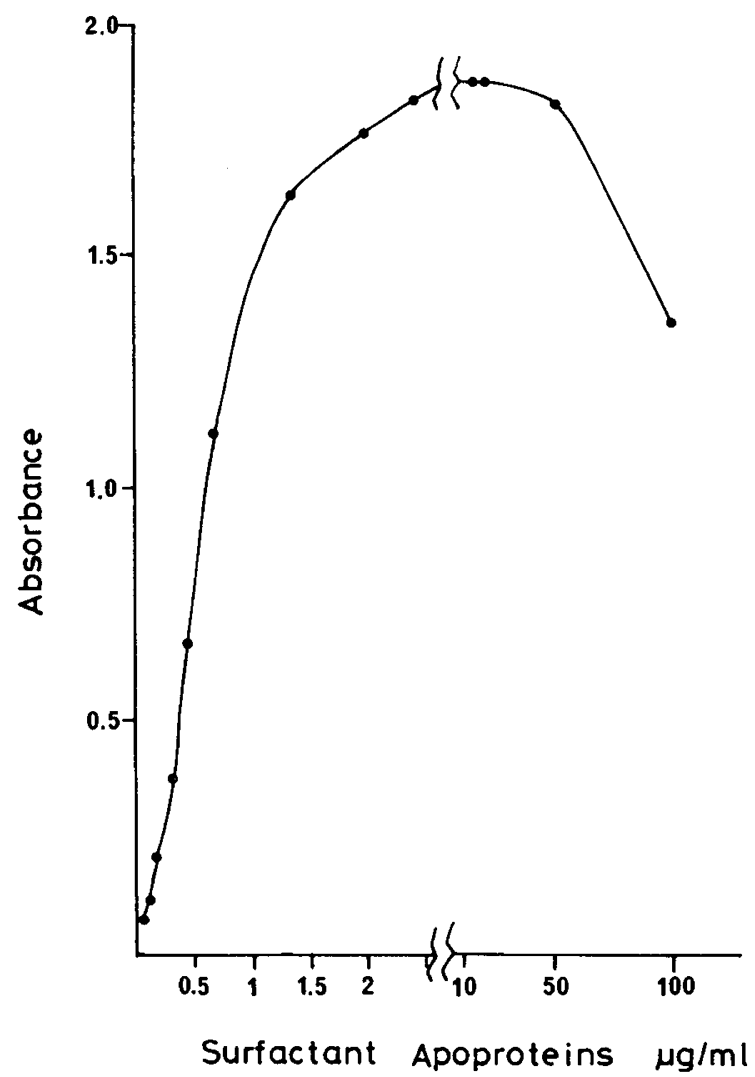

Fig. 3. Two-site simultaneous immunoassay with monoclonal antibodies for the determination of surfactant apoproteins at the high concentrations. Absorbance was measured at $\mathrm{OD}_{500 \mathrm{~nm}}-\mathrm{OD}_{610 \mathrm{~nm}}$. Values are the mean of duplicate assays.

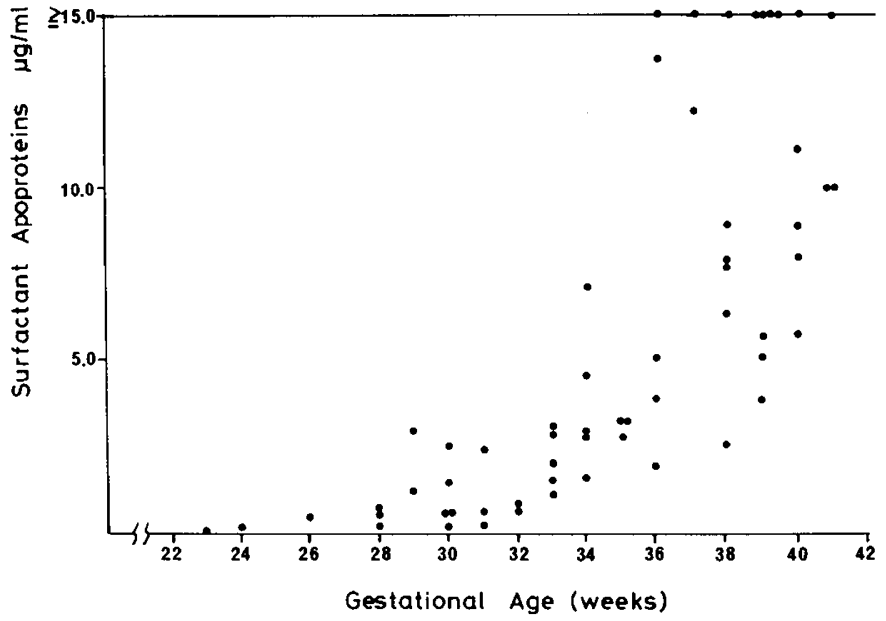

Fig. 4. Surfactant apoprotein concentrations of 59 amniotic fluid samples at 23 to $41 \mathrm{wk}$ gestation. Each point is the mean of duplicate assays.

Table 1. Immunoassay of surfactant apoproteins in human amniotic fluid

\begin{tabular}{|c|c|}
\hline Duration of pregnancy (wk) & $\begin{array}{l}\mu \mathrm{g} \text { apoproteins } / \mathrm{ml} \text { of } \\
\text { amniotic fluid }\end{array}$ \\
\hline$\leqq 30$ & $0.84 \pm 0.23(13)^{*}$ \\
\hline $31-33$ & $1.54 \pm 0.22(10)$ \\
\hline $34-36$ & $5.46 \pm 1.30(13)$ \\
\hline $37-41$ & $13.10 \pm 2.50(23)$ \\
\hline
\end{tabular}

* Values are expressed as mean \pm SE of the number of pools of amniotic fluid given in parentheses.

two monoclonal antibodies which were prepared in our laboratory. The two-site sandwich immunoassay has been developed by utilizing the fact that the monoclonal antibody reacts only to a single determinant in the antigen molecule. The two-site simultaneous immunoassay is the most simple method among the various two-site immunoassays, and it will function better with monoclonal antibodies owing to the lack of competition between the binding sites (15). In the simultaneous immunoassay, two reactions between antigen and antibody, i.e. the apoproteins with immobilized antibody and the apoproteins with biotinylated antibody, can be accomplished in one step. Recently, Katyal and Singh (3) developed the enzyme-linked immunoassay for rat surfactant apoproteins using polyclonal antibodies. The two-site simultaneous immunoassay in the present study is sensitive and reproducible. The immunoassay reported by Katyal and Singh (3) requires about $5 \mathrm{~h}$ to complete after the tubes were precoated with the primary antibody. Alternatively, since the antigen and the biotin-labeled antibody are simultaneously added in the immunoassay reported herein, one step of the incubation and washing can be eliminated. Thus, the present assay is considerably simplified and makes it possible to complete the assay within $2.5 \mathrm{~h}$ after melting the frozen, antibody-immobilized microtiter plates. Another advantage of the present method is the use of two monoclonal antibodies having different epitopes to the antigen, a continuous unlimited supply of which is available.

In the simultaneous immunoassay, the high dose hooking effect was observed (Fig. 3). The biotinylated-antibody apparently tends to bind with the apoproteins that failed to react with the immobilized antibody (16). However, this hooking effect is seen only at extremely high concentrations and can be avoided by multiple dilutions of amniotic fluid samples.

Skim milk seems to work well for blocking, incubating, and washing in the procedure of the immunoassay as compared to bovine serum albumin. The use of skim milk is more effective at lowering the background. It is also useful because skim milk 
is considerably less expensive the comparable amounts of bovine serum albumin (17).

The assay using the avidin-biotin interaction which we used in the present method has several advantages. The binding between avidin and biotin is essentially irreversible and the affinity of avidin to biotin is greater than that of antigen to antibody (18). Furthermore, the procedures of biotinylation can be easily performed and more than two biotin molecules may be linked to a single antibody molecule. These features result in amplifying the sensitivity of the immunoassay $(19,20)$.

Katyal et al. (4) reported on the determination of surfactant apoproteins in human amniotic fluid using polyclonal antibodies. However, there has been no report published regarding the apoprotein concentration in human amniotic fluid at different stages of pregnancies. In the present study we presented data on the apoprotein concentrations in human amniotic fluid from 23 to $40 \mathrm{wk}$ gestation. The concentration of surfactant apoproteins at less than $30 \mathrm{wk}$ gestation was very low (mean $0.84 \mu \mathrm{g} / \mathrm{ml}$ ), and it then increased 6.5-fold from the period of 34 to $36 \mathrm{wk}$ gestation and 15.5-fold after 37 wk gestation. The change in the concentration of amniotic fluid apoproteins with gestational age is very similar to those reported with lecithin to sphingomyelin ratio (21) and saturated phosphatidylcholine (22) in human amniotic fluid. The developing profile of the apoprotein concentration as a function of gestational age is also similar to that of King et al. (2) who determined titers by latex agglutination using polyclonal antibodies as an indicater of the surfactant apoproteins. These results indicate that the fetal lung maturity will be more precisely predicted using the quantitation of surfactant apoproteins with the combination of the lecithin/sphingomyelin ratio or saturated phosphatidylcholine concentration. In conclusion, the simultaneous immunoassay with monoclonal antibodies presented in this study seems to be useful to predict the fetal lung maturity. A continuous unlimited supply of antibodies as well as its high specificity, sensitivity, rapidity, and simplicity makes this assay method useful for clinical application.

Acknowledgment. The authors thank Dr. K. Sasaki, Department of Obstetrics and Gynecology, Asahikawa Medical College, Japan, for providing samples of human amniotic fluid.

\section{REFERENCES}

1. Goerke RJ 1974 Lung surfactant. Biochim Biophys Acta 344:241-261

2. King RJ, Ruch J, Creasy RK 1975 Appearance of apoproteins of pulmonary surfactant in human amniotic fluid. J Appl Physiol 39:735-741
3. Katyal SL, Singh G 1983 An enzyme-linked immunoassay of surfactant apoproteins. Its application to the study of fetal lung development in the rat. Pediatr Res 17:439-443

4. Katyal SL, Amenta JS, Singh G, Silverman JA 1984 Deficient lung surfactant apoproteins in amniotic fluid with mature phospholipid profile from diabetic pregnancies. Am J Obstet Gynecol 148:48-53

5. Köhler G, Milstein C 1975 Continuous cultures of fused cells secreting antibody of predefined specificity. Nature 256:495-497

6. Uotila S, Ruoslahti E, Enbvall E 1981 Two site sandwich enzyme immunoassay with monoclonal antibodies to human alpha-fetoprotein. J Immunol Methods 42:11-15

7. Nishi S, Yamazaki H 1983 Monoclonal antibodies against AFP: application in immunoassay and affinity chromatography. Ann NY Acad Sci 417:452458

8. Kuroki Y, Fukada Y, Takahashi H, Akino T 1985 Monoclonal antibodies against human pulmonary surfactant apoproteins: specificity and application in immunoassay. Biochim Biophys Acta (in press)

9. Frosolono MF, Charms BL, Pawlowski R, Slivka S 1970 Isolation, characterization, and surface chemistry of a surface-active fraction from dog lung. $J$ Lipid Res 11:439-457

10. Laemmli UK 1970 Cleavage of structural proteins during the assembly of the head of bactriophage T4. Nature 227:680-685

11. Lowry OH, Rosebrough MJ, Farr AL, Randall RJ 1951 Protein measurement with the folin phenol reagent. J. Biol Chem 193:265-275

12. Oi VT, Herzenberg LA 1980 Immunoglobulin producing hybrid cell line. In: Mishell BB, Shiige SM (eds) Selective Methods in Cellular Immunology. WH Frieman, San Francisco, pp 351-372

13. Ey PL, Prowse SJ, Jenkin CR 1978 Isolation of pure $\operatorname{IgG}_{1}, \operatorname{IgG}_{2 \mathrm{a}}$ and $\operatorname{IgG}_{2 \mathrm{~b}}$ immunoglobulines from mouse serum using ProteinA-Sepharose. Immunochemistry 15:429-436

14. Towbin H, Staehelin T, Gordon J 1979 Electrophoretic transfer of proteins from polyacrylamide gels to nitrocellulose sheets: procedure and some applications. Proc Natl Acad Sci USA 76:4350-4354

15. Sevier ED, David GS, Martinis J, Desmond WJ, Bartholomew RM, Wang R 1981 Monoclonal antibodies in clinical immunology. Clin Chem 27:17971806

16. Nomura M, Imai M, Usuda S, Nakamura T, Miyakawa $Y$, Mayumi M A pitfall in two site sandwich 'one step' immunoassay with monoclonal antibodies for the determination of human alpha-fetoprotein. J Immunol Methods $56: 13-17$

17. Johnson DA, Gauth JW, Sportsman JR, Elder JH 1984 Improved technique utilizing nonfat dry milk for analysis of proteins and nucleic acids transfered to nitrocellulose. Gene Anal Technol 1:3-8

18. Green NM 1963 Avidin: 1. The use of $\left[{ }^{14} \mathrm{C}\right]$ biotin for kinetic studies and for assay. Biochem J 89:585-591

19. Guesdon J, Ternynck T, Avrameas S 1979 The use of avidin-biotin interaction in immunoenzymatic techniques. J Histochem Cytochem 27:1131-1139

20. Plebani A, Avanzini MA, Massa M, Ugazio AG 1984 An avidin-biotin ELISA for measurement of serum and secretory IgD. J Immunol Methods 71:133140

21. Gluck L, Kulvovich M, Borer RC, Keidel WN 1974 The interpretation and significance of the lecithin/sphingomyelin ratio in amniotic fluid. Am J Obstet Gynecol 120:142-155

22. Torday J, Carson L, Lawson EE 1979 Saturated phosphatidylcholine in amniotic fluid and prediction of the respiratory distress syndrome. $\mathrm{N}$ Engl $\mathrm{J}$ Med 301:1013-1018 